ISCKMC 2020

International Scientific Congress «KNOWLEDGE, MAN AND CIVILIZATION»

\title{
TEACHING AND EDUCATIONAL TECHNOLOGIES FOR CULTURAL AND HISTORICAL MEMORY PRESERVATION IN STUDENTS
}

\author{
Elena Vladislavovna Krasilnikova (a)*, Alla Evgenievna Oganezova (b) \\ *Corresponding author
}

(a) Tver State Agricultural Academy, 7, Marshal Vasilevsky str., Tver, 17042, Russia, gum512@mail.ru

(b) Peoples’ Friendship University of Russia, 10, Miklukho-Maklaya str., Moscow, Russia, allarudn@rambler.ru

\begin{abstract}
The study analyzes the phenomenon of cultural and historical memory and educational technologies for preserving it in students in the system of modern higher education. The focus is placed on destruction of cultural and historical memory in the context of the globalization of modern culture and the crisis of national self-identification, which necessitated the development of a strategy for formation and preservation of memory among young people. A special role of educational institutions in formation of cultural and historical memory as an important educational component is indicated. The study identifies educational subjects and forms of extracurricular work involved in formation of universal competencies responsible for personal development, including preservation of cultural and historical memory. It describes teaching and educational experience of teachers of the Department of Humanities (Tver State Agricultural Academy) and teachers of the Department of Russian as a Foreign Language (Peoples' Friendship University of Russia) in formation and preservation of cultural and historical memory among students. Effective forms of extracurricular work are analyzed. Advantages of the project-based technology, an innovative method to develop cognitive skills and creative initiative of students, are assessed. The projects presented are The World of the Russian Estate, The Holy Places of Russia, The Cultural Space of Small Towns of Russia, Family-Dynasty in the Historical and Modern Space of Russian Culture, Ecology of Historical Memory, On the Roads of War related to formation and preservation of the cultural and historical memory of students.
\end{abstract}

2357-1330 @ 2021 Published by European Publisher.

Keywords: Cultural and historical memory, project activities 


\section{Introduction}

In the context of the ongoing globalization of culture in general and the sphere of education in particular, the problem of national self-identification and the problem of preserving cultural and historical memory as its component are becoming increasingly relevant. It is of particular significance for Russian reality. The socio-cultural crisis of recent decades, which led to the loss of the former Soviet image of Russia, the transformation of ideas about many historical events of the past, had undoubtedly a direct impact on identification processes in modern Russian society (Sladkova, 2008). The country is currently facing a double task: to create a self-identification image that is being formed under the conditions of the new Russia, and to find its worthy place in the global world (Bagdasarova \& Panova, 2007). The priority role in solving this problem is to be played by the Russian education system, the space where the image of the youth who will represent their country in the near future is formed.

\section{Problem Statement}

The problem of cultural and historical memory, the search for teaching and educational technologies for its preservation among students are the most important components in development of a personalityoriented model of education, which is to form a person of culture who can adapt to the conditions of modern reality and self-fulfill as a person with civic consciousness, a sense of belonging to his country, its history and culture.

\section{Research Questions}

In modern humanities, interest in the category 'historical memory' ('cultural-historical memory') is markedly increasing (Repina, 2004). Most scientists agree on regarding it as the ability of public actors to preserve and pass knowledge from generation to generation about historical events, historical figures, about national heroes, about traditions and collective experience of mastering the social and natural world, about the stages of one or another ethnos, nation, people in their development (Akhmetshina, 2014). The value of cultural and historical memory can be compared with an identification code, which is so necessary for preservation of the socio-cultural identity of different peoples. We believe that in the context of globalization, the erasure of national and cultural differences, the need for cultural and historical memory as a guarantor of sociocultural identity is growing even more.

The stability of the collective cultural and historical memory is largely due to its mental nature, deep foundations of collective consciousness. In modern humanitarian knowledge, mentality is usually understood as a historically established structure that determines the structure of thoughts, feelings, behavior, and forms a system of values, norms of an individual or social group. A mental form of consolidating the historical experience of our ancestors determined the main vector of human development, and its main value becomes primarily the preservation of life (largely the life of the collective first), and later the preservation and maintenance of its cultural and historical face.

In modern humanitarian knowledge, an increased interest in mentality is provoked primarily by the attitude to it as an institution responsible for preservation of traditions, acting as an authority that is given 
the right to legitimize certain undertakings, give them spiritual sanction, sanctify or, on the contrary, excommunicate them (Ignatenko, 2009). In our opinion, this explains the position of individual scientists who are inclined to interpret mentality as a moral category that ensures preservation of historical and cultural memory. Only under these conditions can mentality perform the functions of criterion foundations in relation to individual and social consciousness (Baglieva, 2009).

At the same time, despite the historically established stable mental foundations of cultural and historical memory, we are currently witnessing its destruction. In the context of the globalization of culture and the crisis of Russian sociocultural identity, the question suggests itself about a potential radical change in the mentality. Will we soon find ourselves witnessing a different post-Soviet mentality with a new (distorted) historical memory? On the one hand, fundamental changes contradict the very nature of mentality, which aims to remain 'a kind of people's memory of the past, a psychological determinant of the behavior of millions of people who are true to their existing code' in any circumstances, not excluding catastrophic ones' (Ignatenko, 2009). On the other hand, the practice of recent years shows that even such stable category as mentality is a phenomenon capable of being affected from the outside by a rather aggressive post-industrial consumer culture. In this regard, we believe that in addition to 'mental guarantees', additional efforts are required to maintain proper historical memory capable of preserving socio-cultural identity. The state must develop and consistently implement a united strategy for development of the historical memory of the younger generation (Vyazemsky, 2011). Educational institutions are the first to be called upon to play a special role in rehabilitation and maintenance of cultural and historical memory as an identification code.

In these conditions, the role and responsibility for formation of cultural and historical memory of educational institutions and universities in particular, increases even more. In pedagogical practice, the discipline History traditionally takes the key place in this process. According to the Federal State Educational Standard 3+, within this discipline, general cultural competence responsible for 'the ability to analyze the main stages and patterns of the historical development of society for formation of a civic position' is formed. Unfortunately, the new FSES 3++ lacks this competence. It was replaced by universal competence, which the formation of students' ability to perceive the intercultural diversity of society in socio-historical, ethical and philosophical contexts. This formulation does not exclude development of cultural and historical memory. At the same time, we believe that in this case it (cultural and historical memory) does not become goal in itself, but only exists in the context of the formation of a culture of thinking as a whole. In a modern university, this universal competence is to be formed, in addition to the history course, within such disciplines as philosophy, cultural studies, sociology, political science, and psychology. The amount of hours allocated to these humanitarian disciplines is dramatically decreasing from year to year. It seems that in conditions of limited hours for general humanitarian education, a significant amount of work on formation and preservation of cultural and historical memory will shift from the educational to the extracurricular sphere of the university.

The experience of the pedagogical work of the teachers of the Department of Humanities, TSAA (Tver State Agricultural Academy), and teachers of RFL (Russian as a Foreign Language), RUDN (Peoples' Friendship University of Russia), showed that formation of cultural and historical memory becomes most effective when it goes beyond the classroom (Krasilnikova et al., 2015; Krasilnikova et al., 
2020). In this case, we mean extracurricular work, which uses various forms: field lectures, excursions, student scientific conferences, lessons, excursions, project activities of students, etc. Work with students is carried out within the framework of the cultural and educational center created on the basis of the Department of Humanities in Tver State Agricultural Academy and within the framework of the project activities of the teachers from RFL RUDN. Foreign students who have come to study at the Peoples' Friendship University of Russia from other countries need to adapt to the conditions of Russian reality as soon as possible. A significant part of the student contingent in Tver State Agricultural Academy includes Russian young people from neighboring countries, who need education of cultural and historical memory not less than foreign students. Thus, the task of forming an idea of cultural and historical memory is what unites the capital and regional universities.

The main tasks of the extracurricular work performed by university teachers included: civil-patriotic education of students, immersion in the country's historical past and in the space of modern socio-cultural reality; knowledge of other national cultures, building of tolerance; spiritual, aesthetic and ethical education. All these tasks are aimed at formation and preservation primarily of cultural and historical memory as an identification indicator of modern youth.

\section{Purpose of the Study}

The study aims to investigate the phenomenon of cultural and historical memory and present effective teaching and educational technologies for formation and preservation of cultural and historical memory in students, in particular, consideration of project activities as an innovative method of significant pedagogical potential in the modern personality-oriented education model.

\section{Research Methods}

Research methods are chosen based on the problem stated. Thus, the study employed humanities scientific general and special methods: comparative-historical, systemic, and structural-functional. The study analyzed the phenomenon of cultural and historical memory and its place in the system of modern education, functioning in the context of the crisis of the identification component of Russian society. Project activities are recognized as an effective method for formation and preservation of cultural and historical memory.

\section{Findings}

We share the opinion of scientists who define project activities as educational, cognitive, creative or gaming activities, which result in solution to a certain problem presented in the form of its detailed description (Panina, 2013; Stenina, 2012). University teachers consider the project method as one of the innovative technologies based on the idea of developing students' cognitive skills, creative initiative, independent thinking, as well as the abilities to find and solve problems, navigate the information space, predict and evaluate the results of their own activities. The advantage of the project method over other 
interactive pedagogical technologies is its focus on independent activities students are engaged in for a limited period of time. Project activities that provide better mastering of academic subjects and related universal competencies also contribute to formation of super subject competencies in students: research, communication, organizational and management. Project activities can take a worthy place among teaching and educational technologies for preserving cultural and historical memory of students.

Recently, the teachers of Tver State Agricultural Academy and Peoples' Friendship University of Russia have been actively searching for innovative pedagogical technologies using traditional teaching and educational methods. Field lectures, excursions and round tables are a topical educational form that unites university teachers. Among the most significant events held in recent years were: an excursion to the Borodino field dedicated to the 200th anniversary of the Patriotic War of 1812; round table dedicated to the 200th anniversary of the Tsarskoye Selo Lyceum; excursions dedicated to the 1150th anniversary of the Russian statehood (Vladimir-Suzdal) and to the 400th anniversary of the Romanov dynasty (Kostroma, Ipatiev Monastery). These events that introduced students to the monuments of Russian history and culture undoubtedly contributed to formation of historical consciousness and preservation of cultural and historical memory, a necessary condition for civil identification of young people.

A number of events became the basis for the following projects: The world of a Russian estate; Holy places of Russia; Family-dynasty in the historical and contemporary space of Russian culture; Significant names and monuments of Tver region; Ecology of historical memory. Activities organized within the projects were carried out in stages: the problem statement, development of solution to the problem, choice of methods for project implementation, check and defence.

The project The world of a Russian estate is highly popular with students. As part of the project, in the period from 2013 to 2019 students of TSAA and RUDN University visited Kuzminki (the Golitsyn estate), Arkhangelskoye (the Yusupovs estate), Kuskovo (the Sheremetevs estate), Ostafyevo (the Vyazemskys estate), Abramtsevo (the Aksakovs estate), Muranovo (the Tyutchev estate), Shahmatovo (the Blok estate), Serednikovo (the Lermontov estate), and Polenovo (the Polenov estate) The study of the estate culture became a platform for testing the project method, which brought together students of various directions and training programs, bachelors and specialists. At the same time, work on the project dedicated to the world of the Russian estate was not only of purely cultural and historical interest. For instance, reconstruction of the economic side of a traditional Russian estate - organization of an agrarian and animal husbandry - was useful experience for students of an agricultural university required to understand modern agriculture. The main result of the excursions was the selection of research topics on various aspects of estate culture by students.

Cultural and historical memory is the memory of the sacred events that took place in the sacred places of Russia. In Russian multi-confessional culture, historical consciousness has always correlated with religious consciousness. Therefore, the project Holy Places of Russia has become so important and relevant. As part of this project, university students visited the Trinity-St.Sergius Lavra, Optina Hermitage, IosifoVolotsky Monastery, New Jerusalem, Nilo-Stolobenskaya Hermitage, and got the opportunity to get in touch with the values of spiritual culture and to get acquainted with the history of religion, with the peculiarities of Orthodox Russian culture. 
The results of recent studies confirm the fact that self-identification of Russian youth is largely based on restriction to space and territory (Merzlyakova et al., 2014). Local identity is an advantage, which can become the basis for formation of national identity. The projects Cultural space of small towns of Russia, Family-dynasty in the historical and modern space of Russian culture, Significant names and monuments of Tver region allow determination of the content and measure of local cultural and historical memory. As part of these projects, students got involved in the study of their small homeland and family. The study of a small town - 'small homeland, in particular its history, traditions, significant events and names, immersed students in the all-Russian history and made them feel involved in the history of a large country.

The project Ecology of historical memory made it possible to assess the degree of formation of cultural and historical memory and the level of mastering the skill of project activities by students. The project findings were presented at the Interuniversity Scientific and Student Conference (2019). The presented reports Lost and returned monuments of the Bakunin estate (Pryamukhino), White spots in the history of Kalinin's liberation, Forgotten names of the Heroes of the Great Patriotic War (based on the materials about Selizharovsky District), Forgotten Tver sacred places, etc.) are the evidence of the intellectual and spiritual maturity of students, their personal and civic consistency.

The memory of the Great Patriotic War is the most important part of historical memory of the Russian people. Therefore, during the period of active attempts to distort the history of our country and its role in the global historical space, the problem of preserving cultural and historical memory of the Great Patriotic War becomes extremely relevant.

The latest studies of Russian sociological organizations have revealed the features of formation and transformation of historical memory. It becomes obvious that restoration of historical memory of the Great Patriotic War is primarily affected by modern mass media, modern technologies, and the Internet. Therefore, for reproduction of historical memory of the Great Patriotic War, it is extremely important to focus on targeted information and educational activities through all modern information technologies, primarily among young people, who are active users of gadgets. In our opinion, in the educational environment, it is reasonable and effective to conduct extracurricular work for this purpose. These can be not only popular virtual excursions to places of hostilities, the Great Patriotic War museums, etc., but also live excursions, lessons-excursions, lessons-concerts. For example, university teachers of the Faculty of Russian Language and General Education (RUDN) have organized a series of traditional events dedicated to Victory Day over many years: a visit to Poklonnaya Gora, a lesson-concert Victory Day, shared viewing of films about the war followed by discussion in the form of a round table. Tver State Agricultural Academy also has a tradition of celebrating Victory Day. The Roads of War project is highly popular with students to study and restore the memory of significant events and heroes of the Kalinin Front.

We believe that such educational work provides an additional opportunity for Russian and foreign students who study in our country to adequately fit into the world of ideals, value preferences, norms of behavior and communication common to Russians. 


\section{Conclusion}

Thus, the strategic goal of education is formation of the spiritual and moral culture of students, an important component of which should be cultural and historical memory. The efforts made by humanities teachers are not sufficient to solve the problem of preservation of cultural and historical memory. No doubt, it should be solved with active participation of the state and institutions which implement the strategy for development of the cultural and historical consciousness of young people. If we define the process of formation of cultural and historical memory as a conscious activity for development of a system of values and formation of belonging to a certain cultural integrity, we have to state that this process is quite long with late results. However, the result in any case will depend, among other things, on the choice of teaching and educational technologies for preserving cultural and historical memory.

\section{References}

Akhmetshina, A. V. (2014). The concept of 'historical memory' and its meaning in modern Russian society. Current Issues of Soc. Sci.: Sociol., Polit. Scie., Philos., History, 6(38), 5.

Bagdasarova, A. B., \& Panova, M. E. (2007). Civil and ethnocultural identification in the emerging space of modern Russia. Observatory of Culture, 5, 110.

Baglieva, A. (2009). Mentality as a basic constant of ethno-national consciousness. Man and Labor., 9, 60. Ignatenko, T. I. (2009). Mentality as a form of sociocultural continuity. Human. and Socio-econ. Sci., 2, 68.

Krasilnikova, E., Oganezova, A., \& Koutsoni, O. (2020). Innovative education technologies in the modern sociocultural environment Project activity INTED 2020. In Proc. of the 14th Int. Technol., Ed. and Development Conf. (pp. 4004-4009). Valencia.

Krasilnikova, E. V., Tyulina, A. V., Koltsova, A. A. (2015). On the formation of youth identity in the context of development of a humanistic model of education. Modern Probl. of Sci. and Ed., 2. www.science-education.ru/129-21701

Merzlyakova, I. L., Linchenko, A. L., \& Ovchinnikova, E. V. (2014). On the historical consciousness of modern students. Sociol. Res., 12, 93.

Panina, G. V. (2013). New educational technologies in the implementation of education modernization programs. Higher Ed. Today, 12, 22-26.

Repina, L. P. (2004). Historical memory and contemporary historiography. New and Contemporary History, 5, 42-48.

Sladkova, O. B. (2008). Identity crisis in modern Russian society. Observatory of Culture, 3, 8-14.

Stenina, T. L. (2012). Project culture of students: pedagogical context 'formation'. Cultural Issues, 3, 44-48. Vyazemsky, E. E. (2011). Historical policy of the state, historical memory and the content of the school course in Russian history. Probl. of Modern Ed., 6, 89-97. 